\title{
The Manifestations of Positive Leadership Strategies in the Doctrinal Assumptions of the U.S. Army Leadership Concept
}

doi: http://dx.doi.org/10.12775/JCRL.2015.004

\author{
ANDRZEJ Lis ${ }^{\mathrm{a}, \mathrm{b}}$ \\ a The Faculty of Economic Sciences and Management, \\ Nicolaus Copernicus University, Toruń, Poland \\ $\mathrm{b}$ The Doctrine and Training Centre of the Polish Armed Forces, Bydgoszcz, Poland \\ e-mail: andrzejlis@econ.umk.pl
}

\begin{abstract}
The aim of the paper is to identify the manifestations of positive leadership strategies in the doctrinal assumptions of the U.S. Army leadership concept. The components of the U.S. Army leadership requirements model are be tested against the Cameron's (2012) model of positive leadership strategies including: building a positive work climate; fostering positive relationships among the members of an organisation; establishing and promoting positive communication and manifesting the meaningfulness of work.
\end{abstract}

Keywords: military leadership; positive leadership; positive climate; positive relationships; positive communication; positive meaning.

\section{Introduction}

Leadership in the armed forces is considered to be one of the functional components (building blocks) of joint force capabilities (JP 1-02, 2010, p. 128) or an element of combat power unifying its elements and 
multiplying effects (ADP 6-22, 2012, p. 2). The U.S. Army defines leadership as "the process of influencing people by providing purpose, direction and motivation to accomplish the mission and improve the organisation" (ADP 6-22, 2012, p. 1). The process-focused approach means that leadership is not perceived as an inborn feature but as a human competence which can be learned.

The concept of positive organisational scholarship (POS) is one of the ideas which recently emerged in the theory and practice of management (cf. Cameron et al. (Eds.), 2003; Stankiewicz (Ed.), 2013). The variety of concepts and theories related to leadership has been developed and discussed under the umbrella of the positive approach. For instance, the concept of authentic leadership (cf. Luthans and Avolio, 2003; Gardner et al., 2005; Ilies et al., 2005; Walumbwa et al. 2008; Avolio et al., 2009) is listed among the key research areas within the field positive organisational scholarship (cf. Lopes et al., 2009, p. 282). The fundamental state of leadership (cf. Quinn, 2005) is another leadership concept worth mentioning.

Nevertheless, the most comprehensive approach to leadership inspired by POS ideas is positive leadership described as the concept which "emphasizes what elevates individuals and organisations (in addition to what challenges them), what goes right in organisations (in addition to what goes wrong), what is life-giving (in addition to what is problematic or life depleting), what is experienced as good (in addition to what is objectionable), what is extraordinary (in addition to what is merely effective), and what is inspiring (in addition to what is difficult or arduous)" Cameron (2012, p. 2). Similarly, in their study of positive global leadership, Youssef and Luthans (2012a, p. 541) define it as: "the systematic and integrated manifestation of leadership traits, processes, intentional behaviours and performance outcomes that are elevating, exceptional and affirmatory of the strengths, capabilities and developmental potential of leaders, their followers and their organisations over time and across cultures". Positive leadership is considered to be one of the key areas of positive organisational potential (Glińska-Neweś and Stankiewicz, 2013, pp. 27-28; Karaszewski and Lis, 2013, pp. 59-87). Referring to the opinions of experts expressed in the Delphi technique, Karaszewski and Lis (2013, p. 70) describe such an ideal leadership as: “an art of stirring up the people's engagement and their willingness to undertake initiatives to achieve ambitious goals, expectations and aspirations. Such leadership is based on authority, knowledge, 
competencies, social sensitivity and the leader's vision”. What is worth noticing, the aforementioned definitions focus the attention on the aspects of positive deviance.

As observed by Zbierowski and Góra (2014, p. 88), positive leadership is based on the foundation of the following components: "entrepreneurial and optimistic mindset of leaders (Youssef and Luthans, 2012b), building trust between leaders and followers (Mishra and Mishra, 2012), creating the perception of fairness and justice among employees (Mayer, 2012) by following clear rules of appraisal, salaries and promotions" as well as hope (Carlsen et al. 2012). In his comprehensive model of positive leadership, Cameron (2012) identifies the strategies of positive leadership leading to extraordinary high performance. The catalogue of positive leadership strategies includes: building a positive work climate; fostering positive relationships among the members of an organisation; establishing and promoting positive communication and manifesting the meaningfulness of work.

At first sight, the concept of positive leadership seems to be inconsistent with the military context which is traditionally associated with the authoritarian leadership style. Nevertheless, the shifts in the operational environment and the changes within the armed forces observed in democratic nations resulted in redefining the model of military leadership. In his foreword to the doctrine on leadership (ADP 6-22, 2012), general Odierno the chief of staff of the U.S. Army quotes general Bradley who remarked that "Leadership in a democratic army means firmness, not harshness; understanding, not weaknesses; generosity, not selfishness; pride, not egoism".

Therefore, the proposition may be set that contemporary armed forces have incorporated the ideas of positive leadership in order to increase the efficiency and effectiveness of military operations. The aim of the paper is to contribute to the validation of the aforementioned statement through identifying the elements of positive leadership strategies in the doctrinal assumptions of the U.S. Army leadership concept.

\section{Method}

A case study is a research method recommended for exploratory studies aimed at thorough understanding of the phenomenon under the study rather than the analysis of variables (Yin, 2009, p. 8; Wójcik, 2013, p. 
18). Therefore, a single case study method is applied to achieve the aim of the study. According to Yin (2003, as cited in Strumińska-Kutra and Koładkiewicz, 2012, pp. 14-15), a single case study is recommended as a research method when the case is: (1) a critical case to test the theory, (2) operating in unique or unusual circumstances, (3) a typical case of the population, (4) a new, innovative case, or (5) a case studied in the long term perspective. Taking into account the aforementioned inconsistence between the concept of positive leadership and the military context which is traditionally associated with the authoritarian leadership style, analysing the institutionalisation of positive leadership in a military organisation seems to be an interesting critical case study. The following logical deduction is the consequence of such a choice (cf. Flyvbjerg, 2006; Strumińska-Kutra and Koładkiewicz, 2012, p. 13): if a military organisation implements positive leadership strategies, they may be applied to all kinds of organisations.

The process of research design followed the model proposed by Yin (2010; cf. Myers, 2010; Stake, 2010). The focus of the paper was given to the following research questions: (1) how are the strategies of positive leadership incorporated into the U.S. Army doctrines? (2) what are the techniques recommended by the U.S. Army doctrines to build a positive organisational climate, foster positive relationships among the soldiers and Army civilians, promote positive communication and manifest the meaningfulness of service and work for the U.S. Army among its members? As already mentioned, the proposition was set that if a military organisation implements positive leadership strategies, they may be applied to all kinds of organisations. The case of the U.S. Army was chosen to study the implementation of positive leaderships strategies in military organisations. There are at least three reasons supporting such a choice. First of all, the U.S. Army is one of the world leading military organisations among democratic nations. Secondly, it is known for incorporating up-to-date concepts and ideas into its doctrine and regularly testing them in various types of operations around the world. Thirdly, the U.S. Army has the tradition of institutionalising its concept of leadership in military publications of unlimited distribution, which are approved for public release and available online.

The armed forces are formalised organisations which pay attention to codifying their knowledge in doctrines, manuals and regulations. Simultaneously, knowledge combined and codified in military publications is the foundation for knowledge internalisation through 
education and training (Lis, 2014, pp. 62, 69-72). In consequence, military doctrines related to leadership on one hand manifest values and concepts important for the armed forces while on the other hand they provide guidelines for military leaders how to behave as well as how to develop and train future commanders. Therefore, the components of the U.S. Army leadership requirements model established by doctrine publications (ADP 6-22, 2012; ADRP 6-22, 2012) will be tested against the Cameron's (2012) model of positive leadership strategies including: building a positive work climate; fostering positive relationships among the members of an organisation; establishing and promoting positive communication and manifesting the meaningfulness of work.

The analysis of the U.S. Army publications was the main data collection method. The research procedure was conducted in three stages. First of all, the official data base of U.S. military publications released for unlimited distribution ${ }^{1}$ was searched in order to identify the official publications of the U.S. Department of the Army related to the issues of leadership. The search was focused on doctrine and training publications such as: Army doctrine publications (ADPs), Army doctrine reference publications (ADRPs) and field manuals (FMs) as well as Army regulations (ARs) categorized as administrative documents. Secondly, the quantitative analysis was applied to identify the traces of positivity in the U.S. Army leadership concept through studying the frequency of keywords related to positive leadership strategies in the U.S. Army doctrine publications. The analysis encompassed four publications i.e.: ADP 6-22 (2012), ADRP 6-22 (2012), AR 600-100 (2007) and FM 6-22 (2015). Thirdly, the qualitative analysis was conducted to study in details the statements of the aforementioned U.S. Army publications related to four positive leadership strategies proposed by Cameron (2012) and supporting them techniques. The findings from the documentation analysis, considered to be one of the most widespread and useful data collection techniques in the case study methodology (Matejun, 2011, p. 97), were confronted with the models and the body of knowledge available in the literature on positive leadership.

As the data collection toolbox is limited, the requirement of triangulation is not achieved which is considered to be a limitation of the study. Moreover, the study focuses on the statements in military

\footnotetext{
1 The data base is available online at: http://armypubs.army.mil/index.html
} 
doctrines without exploring leader behaviours during operations or training which is another limitation. Nevertheless, as mentioned above, military doctrines are the manifestations of concepts and ideas which are important for the armed forces and simultaneously they establish the foundation for training soldiers and Army civilians. Therefore, the analysis of the "above-the-waterline" aspects may provide valuable findings and the basis for further research.

\section{The concept of leadership in the U.S. Army doctrine publications}

Among the official publications of the U.S. Department of the Army, the issues of leadership are mainly included into doctrine and training publications such as: Army doctrine publications (ADPs), Army doctrine reference publications (ADRPs) and field manuals (FMs) as well as Army regulations (ARs) categorized as administrative documents. The key documents within the field are: the Army doctrine publication on leadership (ADP 6-22, 2012) supported by the Army doctrine reference publication (ADRP 6-22, 2012) and the respective Army regulation (AR 600-100, 2007). In 2014, the contents of the formerly existing field manual on leadership (FM 6-22, 2006) were rescinded and superseded by ADRP 6-22 (2012). Then, the new field manual related to leader development (FM 6-22, 2015) was issued. Moreover, some other publications discussing the issues related to leadership are worth mentioning including: doctrines on mission command (ADP 6-0, 2012) and training units and developing leaders (ADP 7-0, 2012) as well as supporting them reference publications (respectively ADRP 6-0, 2012 and ADRP 7-0, 2012).

The U.S. Army leadership requirement model establishes the guidelines for the leaders regardless of their rank or position within the chain of command. The model sets two categories of requirements: attributes (internal characteristics of a leader) and competencies (actions that leaders are expected to perform). The Army leader attributes are (ADP 6-22, 2012, pp. 5-6):

- character including Army values, empathy, warrior ethos and discipline;

- presence including military and professional bearing, fitness, confidence, resilience and; 
- intellect manifested through mental agility, sound judgment, innovation, interpersonal tact and expertise.

The competencies of Army leaders should be focused on (ADP 6-22, 2012, pp. 5-6):

- leading the Army members, influencing people outside the chain of command, building trust, providing role models and communicating effectively;

- developing - creating positive environment and following esprit de corps, developing themselves, their subordinates and professional standards;

- achieving aims and objectives but simultaneously creating positive conditions within units under their command.

In order to identify the traces of positivity in the U.S. Army leadership concept, the frequency of keywords related to positive leadership strategies in the U.S. Army doctrine publications was counted. The findings are presented in Table 1.

The analysis of data collected in Table 1 indicates that three of four strategies of positive leadership identified by Cameron (2012) are directly manifested in the U.S. Army doctrine publications. These

Table 1. The frequency of keywords related to positive leadership strategies in the U.S. Army doctrine publications

\begin{tabular}{lcccc}
\hline & ADP 6-22 & ADRP 6-22 & AR 600-100 & FM 6-22 \\
\hline Positive climate & 5 & 12 & 0 & 4 \\
\hline Climate & 10 & 86 & 4 & 49 \\
\hline Compassion & 0 & 0 & 0 & 2 \\
\hline Forgiveness & 0 & 0 & 0 & 0 \\
\hline Gratitude & 0 & 0 & 0 & 0 \\
\hline Relationship & 5 & 56 & 4 & 81 \\
\hline Energy network & 0 & 0 & 0 & 0 \\
\hline Strength & 1 & 36 & 2 & 176 \\
\hline Communication & 4 & 38 & 7 & 92 \\
\hline Feedback & 4 & 61 & 11 & 365 \\
\hline Meaningfulness & 0 & 0 & 0 & 0 \\
\hline Well-being & 1 & 8 & 3 & 23 \\
\hline Value & 8 & 134 & 25 & 123 \\
\hline Community & 0 & 0 & 4 & 7 \\
\hline
\end{tabular}


are: building a positive work climate; fostering positive relationships among the members of an organisation and establishing and promoting positive communication. Nevertheless, the Army publications do not mention explicitly some of techniques and activities supporting positive leadership strategies listed in the Cameron's (2012) catalogue. Therefore, the question arises: "what are the military doctrine guidelines and recommendations for developing and supporting a positive organisation climate, positive relationships and positive communication”. As regards the meaningfulness of work, it is not explicitly mentioned in the U.S. Army publications under the study. However, these documents impose on Army leaders the responsibility for well-being of their subordinates and they highlight the paramount importance of cultivating Army values.

\section{Building a positive work climate}

Organisational climate refers "to subjective employee feelings concerning their expectations related to their workplace and an atmosphere in an organisation" (Glińska-Neweś and Stankiewicz, 2013, p. 24). In their classical work, Litwin and Stringer (1968) enumerate the following dimensions of an organisational climate: structure, responsibility, reward, risk, warmth, support, standards, conflict and identity. As regards positive organisational climate, it is characterised by following requirements: fostering employee behaviours oriented to development of an organisation; representing values important for individuals; being shared by the organisation members (Kalińska, 2010, p. 118). Positive organisational climate is described by six dimensions influencing employee well-being and shaping their positive behaviours: clarity of organisation aims, structure, culture and requirements; rewards; organisational standards; the feeling of flexibility; responsibility and autonomy; and commitment (Kalińska, 2010, pp. 118-120). In his work, Cameron (2012, p. 25) highlights the role of emotions in building up a positive work climate which is defined as "a work environment in which positive emotions predominate over negative emotions”. In order to build up a positive organisational climate leaders are recommended to foster compassion, forgiveness and gratitude (Cameron, 2012, pp. 31-43).

Compassion in the organisational context is associated with noticing, feeling and responding to suffering of another person (Dutton et 
al., 2006; cf. Kanov et al., 2004; Lilius et al., 2008). According to the theory of compassion organising competence developed by Dutton et. al. (2005; 2006), individual responses of organisation members to the suffer and pain of others may be coordinated through the process of compassion organising. As observed by Lopes (2009, p. 282): "[c]ompassion is important for business organisations because it influences the activation of people's attention to pain, empathetic concern, and action, to extract and coordinate resources from an organisational system, especially in crisis situations”. The study of compassion capability by Lilius et al. (2011) explains how some everyday practices contribute to the creation of high-quality connections and dynamic boundary-permeability norm which, in consequence, enforce employee noticing, feeling and responding to suffering of another person. In the model of positive leadership proposed by Cameron (2012, pp. 33-36, 135), the leaders behaviours oriented to fostering compassion in difficult or even traumatic moments for the members of their organisations are manifested through: noticing and sharing information about these negative events; showing their emotions and feelings in the public and enabling employees to express compassionate responses.

Fostering forgiveness is the second of techniques recommended by Cameron (2012) to build up a positive work climate. As Cameron observes in one of his earlier works:

Forgiveness in organisations occurs, then, when emotional, attitudinal, cognitive and behavioural changes transpire after harm of wrong-doing has been experienced. Negative feelings, bitterness, resentment, desire for revenge, retaliatory behaviour are abandoned and replaced by a neutralised position at a minimum, and by increase in positive emotions, affirmative motivations, and prosocial behaviours in the ideal." (Cameron, 2007, p. 132).

Fostering forgiveness is particularly important in organisations when some events harmful to employees happen (e.g. downsizing, mistakes) and there is a need to restore positive feelings (Cameron, 2007, p. 136). Recognising an important role of forgiveness for contemporary organisations, Fehr and Gelfand (2012, p. 665) introduce the construct of the forgiveness climate defined as "the shared perception that empathic, benevolent responses to conflict from victims and offenders are rewarded, supported and expected in the organisation”. 
The links between organisational forgiveness and leadership are studied by Cameron (2001) who formulates the prescriptions for leaders willing to encourage forgiveness when their organisations are challenged by traumatic events. In consequence, fostering forgiveness is included by Cameron (2012) as one of the techniques recommended for leaders to build up a positive work climate. According to the model, leaders can foster forgiveness through: acknowledging harmful feelings experienced by employees; focusing employee attention on positive organisational aims; maintaining high standards in an organisation; providing support to employees who participated in harmful events; expressing forgiveness in the language of communication (Cameron, 2012, pp. 36-39, 135).

Showing gratitude is the last but not the least action to build a positive work climate. Park and Peterson (2003) enumerate gratitude among characters strengths of individuals and include it into the Values in Action (VIA) Classification of Strengths. Gratitude is defined as "[b]eing aware of and thankful for the good things that happen; taking time to express thanks" (Park and Peterson, 2003, p. 36) and "positive recognition of benefits received" (Emmons, 2003, p. 82). The acts of gratitude are expected to trigger positive positive outcomes both at the individual and organisational level (Emmons, 2003; Bono et al., 2004). The acts of gratitude occur within the triangle consisting of a benefactor, a benefice (gift) and a beneficiary (Emmons, 2003). While building a positive work climate, leaders are to play the role of a benefactor. Fulfilling this role, leaders have at their disposal the variety of techniques, such as: gratitude visits, letters or journals to express gratitude to their employees (Cameron, 2012, pp. 31-43).

The role of leadership in shaping a positive organisational climate in the military context is analysed by Lis (2015). He identifies the features of organisational climate defined in military doctrines, discusses the responsibilities of military commanders to establish a positive working environment and highlights the importance of trust between leaders and their followers. The U.S. Army doctrines highly value a positive command climate. ADRP 6-22 (2012, p. 2.12) assumes that "[a] positive command climate instils a sense of mutual trust among Soldiers. It facilitates a strong sense of discipline, comradeship, self-respect, and morale. It helps Soldiers develop a desire to do their fair share and to help in the event of need". The role of positive environment is to "lead to individuals who feel better about themselves, 
have stronger commitments, and produce better works" (ADRP 6-22, 2012, p. 7.2). The role of such a climate is to stimulate learning as well as enable soldiers and units to improve and operate in an efficient and effective way (ADP 6-22, 2012, p. 8). As the members of partner organisations (such as governmental, intergovernmental, non-governmental and even private business organisations) may be embedded into the Army units, military leaders are expected to foster a positive command climate including all troops and assigned individuals (ADRP 6-22, 2012, p. 2.3.).

Later, the doctrine highlights the characteristics of a positive climate desired by the U.S. Army describing it as "[a] climate that promotes the Army Values and fosters the Warrior Ethos, encourages learning, promotes creativity and performance, and establishes cohesion" (ADRP 6-22, 2012, p. 10.4). Positive climate is characterised by fairness, inclusiveness and ethics. Fairness means consistent application, freedom from any biases, accurateness and following ethical standards. Inclusiveness ensures that every member of an organisation is integrated. Ethics is manifested through obeying Army values and warrior ethos (ADRP 6-22, 2012, p. 7.2).

U.S. Army leaders are responsible for creating a positive environment based on organisational culture and climate as well as fostering esprit de corps (ADRP 6-22, 2012, pp. 7.1.-7.2). The leader responsibility for building up a positive organisational climate is often emphasised in the U.S. Army doctrines. In his foreword to the Army doctrine on leadership (ADP 6-22, 2012), general Odierno the chief of staff of the U.S. Army points out that "[b]eing a leader is not about giving orders, it's about earning respect, leading by example, creating a positive climate, maximizing resources, inspiring others, and building teams to promote excellence”. As stated in the U.S. Army doctrine on mission command (ADP 6-0, 2012, p. 7; cf. AR 600-20, 2014 , p. 2) the role of commanders is "to establish a positive command climate that facilitates team building, encourages initiative, and fosters collaboration, dialogue and mutual trust and understanding”. "Providing a climate where subordinates have the latitude to explore options" is mentioned among the leader behaviours being the prerequisites for the effectiveness of their organisations (ADP 6-22, 2012, p. 2). Therefore, the Army doctrines recommend leaders to balance their orientations to task accomplishment and people. As stated in the ADP 6-22 (2012, p. 2): “Leaders must balance successful mission 
accomplishment with how they treat and care for organisational members. Taking care of people involves creating and sustaining a positive climate through open communications, trust, cohesion, teamwork”. Building up a positive organisational climate is included into the category of leader competencies to develop (ADP 6-22, 2012, p. 8; ADRP $6-22,2012$, pp. 7.1-7.5, 10.4, 11.6). The catalogue of leader activities aimed at creating a positive environment includes (ADRP 6-22, 2012, pp. 7.2-7.5):

- fostering "teamwork, cohesion, cooperation and loyalty (esprit de corps)";

- encouraging "fairness and inclusiveness";

- encouraging "open and candid communications";

- creating "a learning environment”;

- encouraging "subordinates to exercise initiative, accept responsibility and take ownership";

- demonstrating "care for follower well-being”;

- anticipating “people's on-the-job needs”;

- setting and maintaining "high expectations for individuals and teams”.

Trust, interpersonal tact and leader's empathy are identified as important antecedents for establishing a positive working environment. The leader ability to build trust is listed among lead competencies in the U.S. Army leadership requirements model (ADP 6-22, 2012, p. 7; ADRP 6-22, 2012, pp. 6.7-6.8). Organisational climate is a subjective feeling of organisation members. Therefore, interpersonal tact, listed among the components of the U.S. Army intellectual attributes, is considered to be important for building a positive climate. As highlighted in the U.S. Army doctrine on leadership "[e]ffectively interacting with others depends on knowing what others perceive. It relies on accepting the character, reactions, and motives of oneself and others. Interpersonal tact combines these skills, along with recognising diversity and displaying self-control, balance, and stability in situations” (ADRP 6-22, 2012, p. 5.2). The U.S. Army doctrine highlights the role of leader's empathy for building up positive climate. As stated in the ADRP 6-22 (2012, p. 3.3.) "[t]he ability to see something from another person's point of view, to identify with, to enter into another person's feelings and emotions, enables the Army leader to better interact with others". 


\section{Fostering positive relationships}

The issue of positive relationships at work and their role for organisations attracts the attention of researchers associated with the positive organisational scholarship concept (cf. Dutton and Ragins (Eds.), 2007; Turner de Tormes Eby and Allen (Eds), 2012). As observed by Glińska-Neweś and Stankiewicz (2013, p. 28) "interpersonal relationships define mutual relations among organisation members and between them and people from the outside of an organisation". According to Allen and Turner de Tormes Eby (2012, pp. 6-8), interpersonal relationships can be described by following dimensions: affective tone, emotional carrying capacity, interdependence, intimacy, permanence, power, tensility and trust.

In their study embedded in the context of positive organisational potential, Lis et al. (2014) prove that the aspects related to leadership are strong intra-organisational antecedents of positive interpersonal relationships. They confirm that "interpersonal relationships are much stronger correlated with the attitudes and behaviours of middle managers than with those of top managers" (Lis et al., 2014, p. 45). Fostering positive relationships among the members of an organisation is the second of positive leadership strategies enumerated by Cameron (2012). Recognizing the fact that the variety of activities fostering positive relationships is discussed in literature, Cameron (2012, pp. 53-64) focus attention on: developing positive-energy networks and employee strengths.

Baker et al. (2003) combine the positive organisational scholarship approach with the organisational network analysis in order to study the intensity and quality of positive relationships in organisations. They introduce the distinction between energising networks and de-energising networks observed in organisations and the individuals who are positive energisers and negative energisers. Energisers are organisation members who "spark progress on projects or within groups" while de-energisers are "people who have an uncanny ability to drain the life out of the group" (Cross et al. 2003, p. 51). The process of energy creation is stimulated by interactions which generate visions, enable people to contribute, engage them fully and achieve observable outcomes and progress, and are motivated by hope (Cross et al. 2003). Leaders are recommended to support building positive-energy networks through: establishing for employees the opportunities for serving other 
organisation members; providing a personal role model of positive energy; analysing the energy networks within an organisation in order to support positive energizers and mitigate the influence of negative energizers (Cameron, 2012, pp. 53-59).

Strengths are defined as the abilities "to provide consistent, near perfect ability in a given activity” (Clifton and Harter, 2003, p. 111). Strengths can be considered both at the individual and organisational level (Lopes et. al., 2009, pp. 283-384). The main idea of the approach based on employee strengths is to identify and develop their talents (Clifton and Harter, 2003). The activities aimed at capitalizing employees strengths, recommended by Cameron (2012, pp. 60-63, 135) include: cooperating with outstanding performers, providing opportunities for organisation members to exploit their strengths as well as recognise and celebrate positive outcomes.

As highlighted in the U.S. Army doctrine on mission command (ADP 6-0, 2012, p. 7) commanders are to "understand the importance of human relationships in overcoming uncertainty and chaos and maintaining the focus of their forces. The art of command includes exploiting the dynamics of human relationships to the advantage of friendly forces and to the disadvantage of an enemy".

The U.S. Army doctrine publication on leadership emphasises the role of trust in building positive relationships. As stated in the doctrine (ADP 6-22, 2012, p. 3): “Trust characterises positive relationships. Army leaders build trust by being honest and dependable. Without trust, there will be no relationship, no commitment, and no effective communication among parties”. In order to build trust, military leaders are supposed to provide personal role models, foster positive relationships, engage team members and react to any misbehaviours against trust bonds within a team (ADRP 6-22, 2012, pp. 6.7-6.8).

Although building positive-energy networks is not directly mentioned in the U.S. Army doctrines, leadership is considered as a "multiplier of effects", which among others energizes organisation members and motivates them to achieve ambitious goals (ADP 6-22, 2012, p. 2.). General Odierno in the preface to the U.S. Army doctrine on military leadership (ADP 6-22, 2012) mentions building "agile, effective, high-performing teams" as one of his requirements for military leaders. Applying appropriate methods of influence aimed at energizing followers is listed among the components of the military leaders' competency to lead others. The scope of the aforementioned methods ranges from 
compliance to commitment (ADRP 6-22, 2012, p. 6.7). Moreover, U.S. Army leaders are expected to lead by example and be role models for their followers (ADRP 6-22, 2012, p. 6.12).

Developing others is one of the Army leader's responsibilities which supports subordinates to exploit their strengths. Military leaders are expected to place their subordinates "in best situation to maximise their talent” (ADP 6-22, 2012, p. 8). In order to fulfil this responsibility military leaders are supposed to provide the assessment of developmental needs of organisation members; counsel, coach and mentor; facilitate ongoing development and foster team skills and processes (ADRP 6-22, 2012, p. 7.8-7.15). Moreover, leaders are to allocate necessary resources, establish clear goals and provide "positive, meaningful feedback" to support their followers in exploiting strengths (ADP 6-22, 2012, p. 8). Military leaders are expected to reinforce and improve the performance of their subordinates and units in order to change them into high performing organisations and achieve aims (ADRP 6-22, 2012, p. 8.3).

\section{Fostering positive communication}

Fostering positive communication is the third of positive leadership strategies. Cameron (2012, p. 65) claims that "[p]ositive communication occurs in organisations when affirmative and supportive language of communication replaces negative and critical language”. Defining the desired language of internal communication from the perspective of positive management theory, Wińska (2013, pp. 205-206) describes it as "such form and content (...) which is understandable and adjusted to the recipients, explicit, complete, prompt, and true. It has motivational functions and emphatic functions as well as it explains and supports important organisational values”. Further, in her study, Wińska (2013, p. 206) identifies the following dimensions of positive internal communication: completeness and reciprocity, explicitness and promptness, sharing feelings and emphatic function, supporting integration among employees, explaining and supporting organisational culture. According to Cameron (2012, pp. 72-83), in order to foster positive communication leaders should: provide best-self feedback and use supportive communication.

Cameron (2012) recommends the reflected self based feedback process (cf. Roberts et. al., 2005) as a technique of fostering positive 
communication. Best-self feedback may be encouraged through collecting information from team members on strengths of their colleagues and supporting employees in identifying their positive qualities. Such a feedback emphasizes individual's strengths which in consequence results in the increase in excellence and performance. Moreover, it strengthens relationships among the employees (Cameron, 2012, pp. 74-77).

Using supporting communication to convey negative messages is another technique of the positive communication strategy. The aim of supportive communication is to maintain positive relationships while providing employees with negative feedback or unpleasant information. Supportive communication uses more descriptive statements than evaluative statements. The focus is given to the problem and possible solutions rather than to the evaluation of people (Cameron, 2012, pp. 77-82). The comprehensive catalogue of the attributes of supportive communication is provided by Cameron (2011, p. 243). Such communication should be: congruent, descriptive, problem-oriented, validating, specific, conjunctive, owned and characterised by supportive listening. Moreover, Cameron (2011, pp. 244-246) discusses two techniques recommended for supportive communication i.e. couching and counselling. Their role is especially important for rewarding achievement and correcting problems.

In the U.S. Army, an open communication, in correlation with trust, cohesion and teamwork, is perceived as one of means to build up a positive climate (ADP 6-22, 2012, p. 2). Horizontal and vertical two-sided communication is listed by general Odierno among his expectations for Army leaders stated in the foreword to the doctrine on leadership (ADP 6-22, 2012). Communication skills are listed among the lead competencies within the U.S. Army leadership requirements model. In order to ensure effective communication military leaders are supposed to listen actively, create shared understanding, employ engaging techniques and be sensitive to cultural aspects. Some interesting features of positive communication may be identified among detailed recommendations established by the doctrine. The examples include: tuning "in to content, emotion, and urgency", stating "goals to energise others to adopt and act on them", identifying and solving any misunderstandings" and demonstrating "respect for others" when communicating (ADRP 6-22, 2012, p. 6.12-6.14).

Giving and obtaining feedback is mentioned among the leader activities included into the competency to achieve results. Effectively 
used assessment techniques and after actions reviews (AARs) are the ways to identify lessons and continuously improve the armed forces and military units (ADRP 6-22, 2012, p. 8.4). Nevertheless, AARs are not only a knowledge management tool but first and foremost a means to strengthen integrity and accountability (Davenport and Prusak, 1998, pp. 8-9). The U.S. Army doctrine offers military leaders such techniques to provide their followers with necessary knowledge and feedback as: counselling, coaching and mentoring (ADRP 6-22, 2012, p. 7.10-7.12). The aforementioned techniques enable military organisations to stimulate knowledge socialisation among their members (Lis (2014, pp. 63-64).

\section{Manifesting meaningfulness of work}

Meaningfulness of work is a force shifting employee attitudes towards their organisations from compliance motivated through punishments and rewards to full internalisation of organisational goals. In effect, employees perceive their work like a calling rather than only a job (Cameron, 2012). According to Van Zyl et al. (2010), meaningfulness of work consists of two components: the meaning of work (cf. Wrzesniewski et al., 1997) and psychological meaningfulness (Kahn, 1990; Spreitzer, 1995; May et al., 2004). Meaning of work is defined as "a subjective kind of sense that people make of their work" (Wrzesniewski et al., 2003, p. 297). Psychological meaningfulness is described as "the value of work goal or purpose, judged in relation to an individual's own ideals or standards" (May et. al., 2004, p. 14).

Taking into account the meaning of work, researchers distinguish among three different approaches represented by employees to their work i.e. work as a job, career, and calling (Bellah et al., 1985; Wrzesniewski et al., 1997). As observed by Cameron (2012, p. 87), there is a kind of parallelism between the aforementioned work orientations and the typology of relationships between organisations and their members (i.e. compliance, identification and internalisation) proposed by Kelman (1958; cf. O'Reilly and Chatman, 1996). The more work is perceived as a calling, and the more internalisation relationships are established between employees and their organisations, the higher meaningfulness of work is represented. The meaning of work may be created by the process of "job crafting" which changes the employee approach to their 
task at the workplace, the number of these tasks and relationships with other members of the organisation (Wrzesniewski and Dutton, 2001; Wrzesniewski, 2003; Wrzesniewski et al., 2013).

Cameron (2012, pp. 85-101) considers manifesting the meaningfulness of work as one the strategies of positive leadership. First of all, in order to develop the feeling of meaningfulness of work, leaders are recommended to show to their employees the positive impact of the work on other people. Secondly, the work should be associated with important virtues or values. Thirdly, the long-term efforts and their aims are to be explained to organisation members. Finally, leaders should appreciate employee contribution which support the development of positive relationships and a sense of community within a company.

U.S. Army leaders are expected to apply a wide range of influence methods to energise subordinates and shift their attitudes from compliance to commitment. Besides pressure, legitimating and exchange, the catalogue encompasses more positively oriented techniques such as personal appeals, collaboration, rational persuasion, apprising, inspirational appeal or participation. Military leaders are to establish clear objectives and mission requirements and to communicate them to followers in order to provide motivation and inspiration. Moreover, leaders should enforce standards and balance between mission accomplishment and the welfare of their subordinates (ADRP 6-22, 2012, pp. 6.1-6.7).

According to the U.S. Army doctrines on leadership, by taking an oath soldiers and Army civilian employees promise to follow the Army values including: loyalty, duty, respect, selfless service, honour, integrity and personal courage. Both leaders and their followers are expected to act according to the aforementioned values. Moreover, leaders are responsible for encouraging their subordinates' obedience to Army values. Soldiers and Army civilians are supposed to show their loyalty towards the U.S. Constitution, the Army, their unit and other service men and women. Duty means doing best to fulfil tasks and obligations. Respect to others and treating them as they should be treated are indispensable behaviours for establishing and maintaining a positive organisational climate. Selfless service is about putting the top priority to the nation, the Army, the unit as well as subordinates and colleagues. It means that the military service goes beyond the job obligations becoming, to a certain extent, a calling. Honour is considered as an integrator of Army values providing "the moral compass for 
character and personal conduct for all members of the Army”. Integrity is behaving in a legal, ethical and moral way. Personal courage expresses in physical and moral attitude to dangers and adversities (ADRP 6-22, 2012, p. 3.2-3.3). What is interesting, the names of Army values read as an acronym LDRSHIP which manifests a direct and important relationship between these values and military leadership.

Army values are closely related to the warrior ethos, the service ethos as well as discipline. The warrior and service ethos are "the internal shared attitudes and beliefs that embody the spirit of the Army profession for soldiers and Army civilians alike”. Discipline means the ability to "control of one's own behaviour according to Army values" and a "mindset to obey and enforce good orderly practices in administrative, organisational, training and operational duties" (ADRP 6-22, 2012, p. 3.4-3.5). Military leaders are supposed exemplify the warrior ethos as the role models for their followers (ADRP 6-22, 2012, pp. $6.10,6.12)$.

\section{Conclusions}

The study confirms that the traces of the positive leadership concept are manifested in the U.S. Army doctrine publications related to leadership.

First of all, the doctrines under the study highlight the role of positive organisational climate, provide its characteristics, identify antecedents and clearly define leaders' responsibilities for building a positive work climate. Building up a positive organisational climate is included into the category of leader competencies to develop within the U.S. Army leadership requirements model. When compared against the Cameron (2012) model of positive leadership strategies, the U.S. Army doctrines underemphasize the techniques based on fostering compassion and forgiveness which seem to be important when facing challenging and traumatic events. Due to the risks associated with a military profession, such techniques could be effective when coping with battle stress and other negative emotions triggered by an operational environment. However, this is only an initial proposal which requires more studies to be validated.

Secondly, positive relationships are highly appreciated by the U.S. Army doctrines under the study. The analysis of content shows that the doctrines include some aspects of the techniques recommended by 
Cameron (2012) to develop positive relationships i.e. building positive energy networks and capitalising the strengths of organisation members. Simultaneously, the paramount importance of trust for developing positive relationships emphasised in studied publications is worth noticing.

Thirdly, communication skills perceived as one of means to build up a positive climate are listed among the lead competencies within the U.S. Army leadership requirements model. The Army doctrines recommend leaders to listen actively, create shared understanding, employ engaging techniques and be sensitive to cultural aspects in order to ensure effective and positive communication. As regards providing feedback, military leaders are encouraged to apply after action reviews, counselling, couching and mentoring. Military doctrines under the study pay less attention to the second of positive communication techniques proposed by Cameron i.e. using supportive communication to provide negative messages.

Fourthly, although manifesting meaningfulness of work is not explicitly mentioned in the U.S. Army doctrines on leadership, this aspect of the positive leadership concept seems to be an inborn feature of any armed forces. All the armies highlight that the military profession is not an ordinary job but it is rather a service or a calling. The same applies to the studied publications which emphasize the role of U.S. Army values, the warrior ethos, the service ethos and discipline. The Army values including: loyalty, duty, respect, selfless service, honour, integrity and personal courage are the guidelines showing soldiers and Army civilians the meaningfulness of their work and service.

The paper contributes to the theory through testing the U.S. Army as a critical case study to validate the deduced statement that if a military organisation implements positive leadership strategies, they may be applied to all kinds of organisations. This is due to the fact that military organisations are not traditionally associated with the ideas and approaches represented by the concept of positive leadership. The findings confirm that the assumptions of the positive leadership concept have been institutionalised in the U.S. Army doctrines. Moreover, the paper provides the contribution for practitioners: military commanders and those responsible for developing and training future leaders in the armed forces. For the former, the paper shows which strategies and techniques of positive leadership are valued by the army. For the latter, the paper exemplifies how up-to-date concepts related to leadership 
developed in the academia are incorporated into the military context through institutionalising them in doctrinal publications.

Summing up, through the analysis of the U.S. Army doctrine publications, the study has validated the proposition that contemporary armed forces have incorporated some ideas of positive leadership into their doctrinal assumptions. Nevertheless, this study should be perceived only as a first step to thoroughly explore the field as two directions of further studies seem to emerge. First of all, the analysis of military doctrine publications of other nations is recommended in order to provide the comprehensive picture of the "above-the-waterline” manifestations of positive leadership strategies in the military context, taking into account diversities between the nations. Secondly, the exploration of leaders' behaviours and practices in real life situations is the other direction of further research aimed at testing how doctrinal assumptions are implemented into practice of military service in home bases, training fields and when performing operational duties.

\section{Bibliography}

ADP 6-0 (2012), Mission Command, Headquarters Department of the Army, Washington. Retrieved from http://armypubs.army.mil/doctrine/DR_pubs/dr_a/pdf/ adp6_0_new.pdf. (accessed 12 February 2015).

ADP 6-22 (2012), Army Leadership, Headquarters Department of the Army, Washington. Retrieved from http://armypubs.army.mil/doctrine/DR_pubs/dr_a/pdf/ adp6_2pdf (accessed 14 June 2015).

ADP 7-0 (2012), Training Units and Developing Leaders, Headquarters Department of the Army, Washington. Retrieved from http://armypubs.army.mil/doctrine/DR_pubs/ dr_a/pdf/adp7_pdf. (accessed 12 February 2015).

ADRP 6-0 (2012), Mission Command, Headquarters Department of the Army, Washington. Retrieved from http://armypubs.army.mil/doctrine/DR_pubs/dr_a/pdf/ adrp6_0_new.pdf. (accessed 22 February 2015).

ADRP 6-22 (2012), Army Leadership, Headquarters Department of the Army, Washington. Retrieved from http://armypubs.army.mil/doctrine/DR_pubs/dr_a/pdf/ adrp6_2pdf (accessed 14 June 2015).

ADRP 7-0 (2012). Training Units and Developing Leaders, Headquarters Department of the Army, Washington. Retrieved from http://armypubs.army.mil/doctrine/DR_pubs/ dr_a/pdf/adrp7_pdf. (accessed 22 February 2015).

Allen, T.D., Turner de Tormes Eby, L. (2012), “The Study of Interpersonal Relationships: An Introduction”, in: Turner de Tormes Eby, L., Allen, T.D. (Eds.), Personal Relationships: The Effect on Employee Attitudes, Behavior, and Well-being, Routledge, New York, pp. 3-14.

AR 600-100 (2007), Army Leadership, Headquarters Department of the Army, 
Washington. Retrieved from http://armypubs.army.mil/epubs/pdf/r600_10pdf (accessed 20 June 2015).

AR 600-20 (2014), Army Command Policy, Headquarters Department of the Army, Washington. Retrieved from http://armypubs.army.mil/epubs/pdf/r600_2pdf (accessed 04 December 2015).

Avolio, B.J., Walumbwa F.O., Weber, T.J. (2009), “Leadership: Current Theories, Research, and Future Directions”, Annual Review of Psychology, Vol. 60, pp. 421-449.

Baker, W., Cross, R., Wooten, M. (2003), "Positive Organizational Network Analysis and Energizing Relationships”, in: Cameron, K.S., Dutton, J.E., Quinn, R.E. (Eds.), Positive Organizational Scholarship: Foundations of a New Discipline, Berett-Koehler Publishers, San Francisco, pp. 328-342.

Bellah, R.N., Madsen, R., Sullivan, W.M., Swidler, A., Tipton, S.M. (1985), Habits of the Heart, Harper \& Row, New York.

Bono, G., Emmons, R.A., McCullough, M.E. (2004), "Gratitude in Practice and the Practice of Gratitude”, in: Linley, P.A., Joseph, S., Positive Psychology in Practice, Wiley, Hoboken pp. 464-481.

Cameron, K.S. (2001), “Leadership through Organizational Forgiveness”, Leading in Trying Times, University of Michigan Business School. Retrieved from http://www. centerforpos.org/wp-content/uploads/CPOSweb-TryingTimes-Cameron-LeadershipForgiveness.pdf (accessed 04 December 2015).

Cameron, K.S. (2007), “Forgiveness in Organizations”, in: Nelson, D.L., Cooper, C.L., Positive Organizational Behavior: Accentuating the Positive at Work, SAGE, London, pp. 129-142.

Cameron, K.S. (2011), “Building Relationships by Communicating Supportively”, in: Whetten D.A., Cameron, K.S. (Eds.), Developing Management Skills, Prentice Hall, Upper Saddle River, pp. 233-278.

Cameron, K.S. (2012), Positive Leadership: Strategies for Extraordinary Performance, Berett-Koehler Publishers, San Francisco.

Cameron, K.S., Dutton, J.E., Quinn, R.E. (Eds.) (2003), Positive Organizational Scholarship: Foundations of a New Discipline, Berett-Koehler Publishers, San Francisco.

Carlsen, A., Landsverk Hagen, A., Mortensen, T.F. (2012), “Imagining Hope in Organisations: From Individual Goal-attainment to Horizons of Relational Possibility”, in: Cameron, K.S., Spreitzer, G.M. (Eds.), The Oxford Handbook of Positive Organisational Scholarship, Oxford University Press, Oxford/New York, pp. 288-303.

Clifton, D.O., Harter J.K. (2003), “Investing in Strengths”, in: Cameron, K.S., Dutton, J.E., Quinn, R.E. (Eds.), Positive Organizational Scholarship: Foundations of a New Discipline, Berett-Koehler Publishers, San Francisco, pp. 111-121.

Cross, R., Baker, W., Parker, A. (2003), “What Creates Energy in Organizations?”, MIT Sloan Management Review, Vol. 44, No. 4, pp. 51-56.

Davenport, T.H., Prusak, L. (1998), Working Knowledge: How Organizations Manage What They Know, Harvard Business School Press, Boston.

Dutton, J.E., Ragins, B.R. (Eds.) (2007), Exploring Positive Relationships at Work: Building a Theoretical and Research Foundation, Lawrence Erlbaum, Mahwah.

Dutton, J., Frost, P., Lilius, J., Worline M. (2005), “Explaining Compassion Organizing Competence”, Working Paper, No. 993, Ross School of Business, University of Michigan. 
Dutton, J.E., Worline M., Frost, P.J., Lilius P.J. (2006), “Explaining Compassion Organizing”, Administrative Science Quarterly, Vol. 51, Issue 1, pp. 59-96.

Emmons, R.A. (2003), “Acts of Gratitude in Organizations”, in: Cameron, K.S., Dutton, J.E., Quinn, R.E. (Eds.), Positive Organizational Scholarship: Foundations of a New Discipline, Berett-Koehler Publishers, San Francisco, pp. 81-93.

Fehr, R., Gelfand, M.J. (2012), “The Forgiving Organization: A Multilevel Model of Forgiveness at Work", Academy of Management Review, Vol. 17, No. 4, pp. 664-688.

Flyvbjerg, B. (2006), “Five Misunderstandings About Case-Study Research”, Qualitative Inquiry, Vol. 12, Issue 2, pp. 219-245.

FM 6-22 (2006), Army Leadership: Competent, Confident and Agile, Headquarters Department of the Army, Washington. Retrieved from http://armypubs.army.mil/ doctrine/DR_pubs/dr_a/pdf/fm6_2pdf (accessed 20 June 2015).

FM 6-22 (2015), Leader Development, Headquarters Department of the Army, Washington. Retrieved from http://armypubs.army.mil/doctrine/DR_pubs/dr_a/pdf/fm6_2pdf (accessed 04 December 2015).

Gardner, W.L., Avolio, B.J., Luthans, F., May, D.R., Walumbwa, F.O. (2005), “»Can You See the Real Me? « A Self-based Model of Authentic Leadership and Follower Development”, Leadership Quarterly, Vol. 16, Issue 3, pp. 343-372.

Glińska-Neweś, A., Stankiewicz, M.J. (2013), “Key Areas of Positive Organisational Potential as Accelerators of Pro-developmental Employee Behaviours”, in: Stankiewicz, M.J. (Ed.), Positive Management: Managing the Key Areas of Positive Organisational Potential for Company Success, Dom Organizatora TNOiK, Toruń, pp. 17-34.

Ilies, R., Morgeson F.P., Nahrgang, J.D. (2005), “Authentic Leadership and Eudaemonic Well-being: Understanding Leader-follower Outcomes”, Leadership Quarterly, Vol. 16, Issue 3, pp. 373-394.

JP 1-02 (2010), Department of Defense Dictionary of Military and Associated Terms, U.S. Joint Staff. Retrieved from http://www.dtic.mil/doctrine/new_pubs/jp1_0pdf (accessed 20 June 2015).

Kahn, W.A. (1990), "Psychological Conditions of Personal Engagement and Disengagement at Work", Academy of Management Journal, Vol. 33, Issue 4, pp. 692-724.

Kalińska, M. (2010), “Pozytywny klimat organizacji jako pożądany efekt Pozytywnego Potencjału Organizacji”, in: Stankiewicz, M.J. (Ed.), Pozytywny Potencjał Organizacji: Wstęp do użytecznej teorii zarzq̨dzania, Dom Organizatora TNOiK, Toruń, pp. 107-140.

Kanov, J.M., Maitlis, S., Worline, M.C., Dutton, J.E., Frost, P.J., Lilius, J.M. (2004), "Compassion in Organizational Life", American Behavioral Scientist, Vol. 47, Issue 6, pp. 808-827.

Karaszewski, R., Lis, A. (2013), "The Role of Leadership to Stimulate Pro-developmental Positive Organisational Potential”, in: Stankiewicz, M.J. (Ed.), Positive Management: Managing the Key Areas of Positive Organisational Potential for Company Success, Dom Organizatora TNOiK, Toruń, pp. 59-87.

Kelman, H.C. (1958), “Compliance, Identification, and Internationalization: Three Processes of Attitude Change”, Conflict Resolution, Vol. 2, Issue 1, pp. 51-60.

Lilius, J.M., Worline, M.C., Maitlis, S., Kanov, J.M., Dutton, J.E., Frost, P. (2008), “The Contours and Consequences of Compassion at Work”, Journal of Organizational Behavior, Vol. 29, Issue 2, pp. 193-218. 
Lilius, J.M., Worline, M.C., Dutton, J.E., Kanov, J.M., Maitlis, S. (2011), “Understanding Compassion Capability”, Human Relations, Vol. 64, Issue 7, pp. 873-899.

Lis, A. (2014), "Knowledge Creation and Conversion in Military Organizations: How the SECI Model is Applied Within Armed Forces”, Journal of Entrepreneurship, Management and Innovation, Vol. 10, Issue 1, pp. 57-78.

Lis, A. (2015), "The role of Leadership in Shaping a Positive Organizational Culture and a Positive Organizational Climate: The case of Military Organizations”, in: Raczyńska M., Krukowski K., Siemiński M. (Eds.), Managing Public Organizations in Theory and Practice, Wydawnictwo Uniwersytetu Warmińsko-Mazurskiego, Olsztyn, pp. 65-75.

Lis, A., Glińska-Neweś, A., Kalińska, M. (2014), “The Role of Leadership in Shaping Interpersonal Relationships in the Context of Positive Organizational Potential”, Journal of Positive Management, Vol. 5, No. 4, pp. 28-49.

Litwin, G.H., Stringer, R.A. (1968), Motivation and Organizational Climate, Harvard Business School, Cambridge.

Lopes, M.P., Cunha, M.P., Kaiser, S., Müller-Seitz, G. (2009), "Positive Organizational Scholarship: Embodying a Humanistic Perspective on Business”, in: Spitzeck, H., Pirson, M., Amann, W., Khan, S., Kimakowitz, E. (Eds.), Humanism in Business: State of the Art, Cambridge University Press, Cambridge, pp. 278-298.

Luthans, F., Avolio, B. (2003), “Authentic Leadership Development”, in: Cameron, K.S., Dutton, J.E., Quinn, R.E. (Eds.), Positive Organizational Scholarship: Foundations of a New Discipline, Berett-Koehler Publishers, San Francisco, pp. 241-258.

Matejun, M. (2011), "Metoda badania przypadków w naukach o zarządzaniu”, Ekonomika i Organizacja Przedsiębiorstwa, No. 10, pp. 93-102.

May, D.R., Gilson, R.L., Harter, L.M. (2004), “The Psychological Conditions of Meaningfulness, Safety and Availability and the Engagement of the Human Spirit at Work”, Journal of Occupations and Organizational Psychology, Vol. 77, Issue 1, pp. 11-37.

Mayer, D.M. (2012), “A Positive Lens on Organisational Justice: Toward a Moral, Constructive, and Balanced Approach to Reactions to Third Party (In)justice”, in: Cameron, K.S., Spreitzer, G.M. (Eds.), The Oxford Handbook of Positive Organisational Scholarship, Oxford University Press, Oxford/New York, pp. 316-324.

Mishra, A.K., Mishra K.E. (2012), "Positive Organizational Scholarship and Trust in Leaders”, in: Cameron, K.S., Spreitzer, G.M. (Eds.), The Oxford Handbook of Positive Organizational Scholarship, Oxford University Press, Oxford/New York, pp. 449-461.

Myers, M.D. (2010), “Case Study Research”, in: Frenz, M., Nielsen, K., Walters, G. (Eds.), Research Methods in Management, SAGE, London, pp. 227-248.

O’Reilly, Ch.A., Chatman, J.A. (1996), “Culture as Social Control: Corporations, Cults and Commitment”, Research in Organizational Behavior, Vol. 18, pp. 157-200.

Park, N., Peterson, Ch.M. (2003), “Virtues and Organizations”, in: Cameron, K.S., Dutton, J.E., Quinn, R.E. (Eds.), Positive Organizational Scholarship: Foundations of a New Discipline, Berett-Koehler Publishers, San Francisco, pp. 33-47.

Quinn, R.E. (2005), "Moments of Greatness: Entering the Fundamental State of Leadership”, Harvard Business Review, July-August, pp. 75-83.

Roberts, L.M., Dutton, J.E., Spreitzer, G.M., Heaphy E.D., Quinn, R.E. (2005), “Composing the Reflected Best-Self Portrait: Building Pathways for Becoming 
Extraordinary in Work Organizations”, Academy of Management Review, Vol. 30, No. 4, pp. 712-736.

Spreitzer, G. (1995), "Psychological Empowerment in the Work Place: Dimensions, Measurement, and Validation”, Academy of Management Journal, Vol. 38, Issue 5, pp. 1442-1465.

Stake, R.E. (2010), “Jakościowe studium przypadku”, in: Denzin, N.K., Lincoln, Y.S. (Eds.), Metody badań jakościowych (Vol. 1), PWN, Warszawa, pp. 623-654.

Stankiewicz, M.J. (Ed.) (2013), Positive Management: Managing the Key Areas of Positive Organisational Potential for Company Success, Dom Organizatora TNOiK, Toruń.

Strumińska-Kutra, M., Koładkiewicz, I. (2012), “Studium przypadku”, in: Jemielniak, D. (Ed.), Badania jakościowe: Metody i narzędzia (Vol. 2), PWN, Warszawa, pp. 1-40.

Turner de Tormes Eby, L., Allen, T.D. (Eds.) (2012), Personal Relationships: The Effect on Employee Attitudes, Behavior, and Well-being, Routledge, New York.

Wińska, J. (2013), “Language of Internal Communication in Creating Pro-developmental POP Outcomes”, in: Stankiewicz, M.J. (Ed.), Positive Management: Managing the Key Areas of Positive Organisational Potential for Company Success, Dom Organizatora TNOiK, Toruń, pp. 203-227.

Yin, R.K. (2003), Case Study Research: Design and Methods, SAGE, Thousand Oaks. Yin, R.K. (2009), Case Study Research: Design and Methods, SAGE, Thousand Oaks. Yin, R.K. (2010), “Designing Case Studies”, in: Frenz, M., Nielsen, K., Walters, G. (Eds.), Research Methods in Management, SAGE, London, pp. 185-226.

Youssef, C.M., Luthans, F. (2012a), "Positive Global Leadership”, Journal of World Business, Vol. 47, Issue 4, pp. 539-547.

Youssef, C.M., Luthans, F. (2012b), "Psychological Capital: Meaning, Findings and Future Directions”, in: Cameron, K.S., Spreitzer, G.M. (Eds.), The Oxford Handbook of Positive Organizational Scholarship, Oxford University Press, Oxford/New York, pp. 17-27.

Van Zyl, L.E., Deacon, E., Rothmann, S. (2010), “Towards Happiness: Experiences of Work-Role Fit, Meaningfulness and Work Engagement of Industrial/Organisational Psychologists in South Africa”, South African Journal of Industrial Psychology, Vol. 36, No. 1.

Walumbwa, F, Avolio, B., Gardner, W., Wernsing, T., Peterson, S. (2008), “Authentic Leadership: Development and Validation of a Theory Based Measure”, Journal of Management, Vol. 34, Issue 1, pp. 89-126.

Wójcik, P. (2013), “Znaczenie studium przypadku jako metody badawczej w naukach o zarządzaniu”, E-mentor, 2013, No. 1(48), pp. 17-22.

Wrzesniewski, A. (2003), “Finding Positive Meaning in Work”, in: Cameron, K.S., Dutton, J.E., Quinn, R.E. (Eds.) (2003), Positive Organizational Scholarship: Foundations of a New Discipline, Berett-Koehler Publishers, San Francisco, pp. 296-308.

Wrzesniewski, A., Dutton, J.E. (2001), “Crafting a Job: Revisioning Employees as Active Crafters of their Work”, Academy of Management Review, Vol. 26, Issue 2, pp. 179-201.

Wrzesniewski, A., McCauley, C., Rozin, P., Schwartz, B. (1997), “Jobs, Careers and Callings: People’s Relations to Their Work”, Journal of Research in Personality, Vol. 31, Issue 1, pp. 21-33.

Wrzesniewski, A., LoBuglio, N., Dutton, J.E., Berg, J.M. (2013), “Job Crafting and 
76 Andrzej Lis

Cultivating Positive Meaning and Identity in Work”, Advances in Positive Organizational Psychology, Vol. 1, pp. 281-302.

Zbierowski, P, Góra, K. (2014), Positive Leadership: Its Nature, Antecedents and Consequences, Journal of Positive Management, Vol. 5, No. 1, pp. 85-99. 